University of Rhode Island

DigitalCommons@URI

Open Access Master's Theses

6-1-1929

\title{
The Use of Certain Crop Plants in the Determination of "Active" Aluminum in the Soil as Compared with Extraction by Dilute Acetic Acid
}

Waldo Lawrence Adams

University of Rhode Island

Follow this and additional works at: https://digitalcommons.uri.edu/theses

\section{Recommended Citation}

Adams, Waldo Lawrence, "The Use of Certain Crop Plants in the Determination of "Active" Aluminum in the Soil as Compared with Extraction by Dilute Acetic Acid" (1929). Open Access Master's Theses. Paper 835.

https://digitalcommons.uri.edu/theses/835

This Thesis is brought to you for free and open access by DigitalCommons@URI. It has been accepted for inclusion in Open Access Master's Theses by an authorized administrator of DigitalCommons@URI. For more information, please contact digitalcommons-group@uri.edu. 


\section{1,4 ad 19

THE USE OF CERTAIN CROF PLANTS

IN THE DETERUINATION OF "ACTIVE" ALUMINUM IN THE

SOIL AS COAPARED WITH EXIURACTION BY DILUTE ACETIC ACID

A thesis subnitted to the Feoulty of the Rhode Island State College in partial fulfillmont of the requiremonts for the degree of Master of Sclence

by

Waldo Lawrence Adams

June 1, 1929. 


\section{IITERATURE.}

PROCEDURE.

Mathods for the Determingtion of Aluminum.

\section{8.}

\section{Description ef So11s.}

Tablo 1.-Dercription of 80118 , fertilizer treatmont. pH.

11me requirement, and yields of splnach on 80118 used.

Acld Extraction of Solls.

Tablo 2.-Actual and relative "active" eluminum content of 80118 as show by extrection with three strongths of acetic acid.

Disoussion of Regults on Solls.

Crope.

Orops grown in Solution Cultures.

Table 3.-Aluminum in crops grown in solution cultures by

\section{Molean.}

Glosshouse Cul ture.

Disousefon of Bosults rith Plents.

Broluheat.

Table 4. Helghts of buokihoat, alumiman content, and mi111grams remoted by crop.

M111et.

Table 5. Melents of millet. aluminrm content, and mill1grams removed by crop.

Oate.

Table 6.-We1ghts of oets, alvuinum content, and nil11grams removed by crop. 
F1gure 1.-Shoming the relation between $\mu_{2} \mathrm{O}_{3}$ in the soll and in the plant.

\section{SUMMARY}

corrcLus IORS

IITHERATURE CITED. 
THE USE OF CERTAIN CROP PLANTS IN THE DETLRMINATION OF "ACTIVE"

ITOIINUN IN THE SOIL AS CONPARTD WITE EXIRACTION BY DILUTE ACETIC ACID.

\section{INTRODUCTION AND STAMEMENT OF FROBIFM}

For more then twenty years much attention and study bas been given by faronomists, plant physlologlsts, and 011 chomlsts to the elemont almainum, Its compounds, and thelr effects upon plant growth:

Many attempts have been made to determine nactive" aluminum in the coll as related to 1 ts effect on plant growth. To date however 11 ttle agreement has been obtained wh the various chemical methods between the mounts of "activen aluminum found end actual depression of frowth. In this problem an attempt was made to determine if the removal of aluminum by crops correlates better with aluminum toxicity than doos pH or reak acid extraction, toxicity haring been denonstreted agronomiax118.

\section{LITERATURE}

Among earlier workers there was muoh difference of opinton concernIng the relation between acid solls and aluminum toxiolty as to whether the acidity per se, or the aluminum made soluble by the acidity was the canse of the dopression in the growth of plants.

The Ilrst to call attention to the possible torio effects of salts of Alunimum were Lbbott, Connor and Smalley $(1)^{2}$ who, working with marshy altuations, found solls which were ungroductive, elthough falrig well axplied with plant lood. They conclude that the nitrate in the soll Was, in part, combined with aluminum and inferred that aluminum nitrato was responsible for the umproductiveness of the 8011 in questlon.

1 Referenoe 18 made by number to "Literatare C1ted." 
In contrest to the opinion of those workers, are the conclusions of gartivell and Pember (12) (13) who, worling with solution cultures, sand oultures, and s0118 from the experimental plats of the Rhode Island Agrioultural Byperiment Station, decided that the eluminum Ion, rather than any aingle alominum aelt, was responsible for the effects noted in the growth of rye and barley.

Iumerous other workers have demonstrated the toxiclty of aluminum and Its calte upon plant growth. Ruprecht (27) cleims that aluminum mphate, when present in culture solutions in concentrations of more then 40 p. p. In., has a very toxto action on clover seedlings. Mirasol (24), worting with weet clover, Inds that in the absence of calcim, aluminum is toxic when applied in amounts chomically equivalent to the acidity of the soll and fatal when applled in anounts chomically equivalent to flve times the acidity of the so11. Yyater (25) considere elumiarm chloride toric to rice seedlings in ooncentrations greater than 17/7500. Hoffer (14) chows a definite connection between the presence of alminum and iron selts in the s011. and root-rot in corn. Fardy (12), and Connor and Sears (7) conflrm the conclusions of Hartwell and Pember that the aluminum 10n is responsible for the toxio effects.

In contrast to the above oplnions is the contention of Iine (17) Who clalms that tho toxic aluminum theory of acld solls is not tenable and that the depression of pleat growth in culture solutions due to the preclpitation of phosphorus as aluminum phoaphate or to increased acldity. G1e (10) states that from investigations which have been conducted thus far It does not appear to have been establishod that aluminum salts are toxic to plants in the same sense as are mercury or copper.

Corel (8) Ilnds aluminum arlphate to be beneficlal to rhododendrons, thoberries, and hydrangta when used in ac1d so11s.

The quantities of alunimum and its compounds wich are toxic to 
plants appear to vary $\mathbf{w t h}$ different plants. The medium used, whether sand, colution cultures, or different solls, is also important. Yolean and G1lbert (28) (23) found a wide variation in the sens1tireness of plants when grown in solution oultures. Lettuce, beets, and radighes were the most sensitive, sorghom and berley were pleced In a modium class, and turnips and redtop were the least sensitive. These same authors found that very amall amounts of aluninum (3-13 p.p.m.) were stimlating but that higher concentrations were toxic. They also noted that, by using the haematoxylin test, the alcuminum absorbed by the plents accumalated only in the cortex, mandy in the protoplasin, and also appeared to be concentrated in the nuclel.

Stolelasa (30) finds that small quantitles of aluninum are stimulating to the plant, and that aluminum chloride and aluminum sulphate in solls do not have the same toxic effect as in solution. The richer the soll in organic matter, the stronger the concentration of aluminum salts the plant can tolerate.

Yaglstad $(20)$ cleims that at acidities 1088 than pH 5.0 alfalfe. red olover, rye, and oets suffered l1ttle or no aluminum injury Fhile corn and beans were 1njurlously affected. Sinoe most of the acid solls found under fleld conditlons fall within the range of $\mathrm{pH} 5.0$ to 7.0 , the beneficial effects due to lime result from a decrease in acidity and not from a decrease in the soluble aluminum present.

Yoohl1 (32) recently reports that Aspergillius niger wi thstands sonoentretlons of aluminum sulphate up to $0.005 \mathrm{~K}$ or $4.16 \mathrm{p}$. p. m. of Anminum, podes cannadensis is dameged by 0.0011 or $0.83 \mathrm{p}$. p. m. of Cominow, while in more dilute solutions new sprouts and roots are 10rmed. Rperiments with many higher plants show an $0.002 x$ solution or $1.66 \mathrm{p}$. p. m. of aluminum to be toxic but that more dilute solutions are atimalating. 
Donnison (9) olaims that soluble aluminum salts stimulate ammonilioation but affect nitrification adversely, especially with increased concentrations of the salt. Somer (29) found that all plants in thalr natural state absorb aluninum. Adaltions of this to culture solutions in which pea were growing, gave only small increase in dry wight but slightly greater increases in seed. With millet, aluminum gave marked Increase in growth and great increase in the quantity of seed. Samner concludes that aluminum is essentall to the normal derelopment of the plant.

Rrateman (16) using a microchemical mothod based upon the formation of a double sulphate of cresiom and alvnima, examined sereral hundrod plants, ropresenting many botanloal families, and found aluminum to be prosent quite extensively, certain species belng much richer in this ubstance than others.

Mocellum (21) and his assoclates, using a spectographic method, de- lare that aluminum is not a constituent of elther plant or animal matter. In direct contradiotion to this is the recently published work of Trulonberg and Class (35). These mon, ueing a H1lger quart priam spectograph, as did Yocellum, found aluminum to be presont in eggs, cerrots, potatoes, lean beef, beef tendons, and varlous other materiels. As the netural result of the observed injurlous effects of lumirum and Its selts, various remedies have been proposed and tried. Fartwell and Pember (12), by use of lime on ac1d so1ls, reduced toxiclty. thoy consider that the advantege of phosphorue and 11 me may often be due as mach to the inactivation of the aluminum as to the effect of the calclim in reducing acidity. Bargoss and Pember (5) by use of largo quantities of upperphosphate, reduced the solubility of aluminum in weak colds.

Donnison (9) claims that calcium carbonate is tho most effective naterial for reducing the toxic action of aluminum alts on nitrifleation 
Iuprecht $(27)$ belieres that the toxic effect of Iron and aluminum can. In a large measure, be overcome by calcium carbonate. Mirasol (24) adrences the 1dea that oalcium carbonate corrects toxicity by precipitating the aluminum as calclum alpminate and that superphosphate at the rate of 400 pounds per acre reduces toxiclty by forming an insolublo phosphate of aluminum. Burtoss and fember (5) report that both greenhouse and fleld observations indicate that large amounts of decaying organio matter (compost, manure or green manure) are efriolent in emberacting the deleterious effects of "active" aluminum upon sensitive orops such as lettuce, spinach, and beots.

\section{PROCEDURE}

\section{Methods for the Determination of Aluminum}

Somewhat more than four yoars ago the writer had ocoasion to make a ceries of aluminum determinations upon solls, and in connection with that work varlous methods for the determination of aluminum were studied. Iron uemally occurs with aluminum and 18 a disturblng factor because of the diffoulty of obteining a complete separation of the two elements. Phosphorus is another source of trouble in wording with crops and solls.

Scott (28) gives various methods for the gravimetrio determination of aluminum. 'Blum (3) has also published a gravimotric mothod. Both of these mothods are satisfactory for the determination of aluminum alone or when large amounts are present, but are useless when quant1t1es as anall as 30 p. p. In. or 108 are to be determined.

Iundell and Knowles (19) and Patten (26) recomend the preolpltation of iron and aluminum together as phosphates. This procedure requires the addition of $20 \mathrm{cc}$. of a 10 per cent ammonium hydrogen phosphete volution, followed by dilute amonium hydroxide until the color of the solution just changes from blue to jellow, using thymol blue 28 an Indicator. Twenty-five co. of 25 per cent amonium acetate are 
added and the solution bolled, filtered, and washod with a hot 5 per oont colution of amnonium nitrate. It is then ignited.

The 1ron is determined in a separate portion of the material and the amount deducted from the weight of combined fron and aluminum phosphates, thus obtaining the aluminum by difference.

ragistad (20) also precipitated Iron and aluminum together as phosphates at pH 5.0 and determined the 1 ron in a separate portion and caloulated the aluminum by difference. Those mothods are not eatisfactory for the reason that the tron mast be determined separately and deducted from the combined phosphates. Whon small quantities of eluminum are present any error in the amount of Iron would also effeot the aluminum.

With the abore method 1 very often happened that on 1gnition the precipitate, instead of being pure white ferric phosphate was colored more or less red, Indicating that some lron had been precipitated as forric hydroxide, thus introdncing an error for the welght of combined phosphatos.

Atack (2) has publishod a colorimotric method which depends upon the formation of an aluminum lake with Allzarin S. Thls mothod in our hands was most unsatisfactory in the presence of Iron and phosphoras, although Ilpmen (18) considers the Alizarin method dependeble.

The mothod adopted at that time was that of Patten (26). The so1l oxtract or ashod plant material was hoated with agua rogla, oraporated to dryness, taken up with HCl (1-1) and again evaporated, heated for one hour at $110^{\circ} \mathrm{C}$. to dehydrate sillca, again taken up with BCl (1-5) Iiltered and washed free. Irom chlorine and the solution made up to a volume of $100 \mathrm{cc}$. Alumimam and iron were precipltated together as phosphate by the addition of $20 \mathrm{cc}$. of 10 per cent solution of sodive acle phomphate, nextrallelag with dilute ammonium hydroxide just to the mpearance of a jollow color, uelng thymol blue as an indicator; adding 
2500 . of a 25 per cent solution of amonium acetate, heating to $70-80^{\circ} 0$. for trenty minutes, allowing to stand, filtering, washing with hot 5 per acht monium nitrate solution, igniting and wolghing as combined phosphates of iron and alumimum. Iron was determined in a separate portion nolng the Jones reductor and titrating with potessium permanganate solntion. The amount of Iron phosphate subtracted from the combined phosphetes give the aluminum phosphate which was oaloulated to eluminum oxdde and so reported. The same oritiolsm applies to this mothod as to that of laglstad regarding the precipitation of basic aluminut hydroxide. Ucing the above method. mumerous determinatlons were made on solls and plant materials. The method wes reasonsbly atisfatory when apprecIable emounts of aluminum were present but with large quantities of iron and amell amounts of al uninum its accuracy was questioned.

Since the accuracy of the above method was questionable under certein conditions the recently published method of Yoe and H111 (31) proved of interest. This method is intended for the colmrimetric determination of alunimum in water using aluminos (The Amnonium Selt of Aurin Tricarboxylic dcld). The writer had the opportunity to oollaborate with the Aepartwent of chomistry of the Michigan Agricultural Byperiment station in adepting this wethod to the determination of amall amounts of aluminem In soll extracts and in plant materials. Yany determinations were made on arthotic solutions contalning known quantities of alumimm, iron, Dhosphorus, celcium, and magnesia ant1l it was poselble to obtain agreement within a 10 per cent error between the quantities of alminum added and those found.

Ihls wethod is as follows for plant meterlal. Iwo to trenty-f1ve crams of dry t18sue are charred over a llames the char extracted $W 1$ th hot wator and f1ltered through ashless paper. The paper and residue are lenited in an electric muffle, kept below redness, and washod into the bakes used to contain the hot water extract, w1th HCI (1-3). B1re ce. 
of conoentrated $\mathrm{HWO}_{3}$ are added and the solution evaporated to dryness.

It is taken up with HCl(1-1), again evaporated to dryness, heated at $110^{\circ} \mathrm{C}$. for one hour, taiken up with HCl $(1-5)$, f11tered and weshed free from chlorides. The finel volume 18 made to 25,50 , or 100 oc. dependIng on the amount of dry material taken and its expected aluminum contont. $\triangle$ so11 solution or extrect is twated in the same manner after the $\mathrm{HCl}$ and $\mathrm{HrO}_{3}$ are added.

Iron and aluminum are separated in the following manner. Five or $10 \mathrm{co}$. of solution are plaoed in a centrifuge tube heving graduations at 10 and 2000. water 1s added to make a volume of $10 \mathrm{co}$. and 0.1 gram amonium hydrogen phoephate and a few drops of thymol blue are added. Icatralize with dilute ammonium hydroxide unt1l the solution just turns blue, then add $1 \mathrm{cc}$. of saturated ammonivm acetate solution. Let stand 30 minutes at room temperatare.

Contrifuge, decant, and wash the precipitate with $3 \mathrm{co}$. of 5 per - ont andonium nitrate solution. The mixture is again centrifuged and decanted. Diseolre the 1ron and aluminum phosphetes in the centrifuge tube, adding $0.5 \mathrm{cc}$. of 6N HCl, dilute to $5 \mathrm{cc}$. wlth water, add $2.5 \mathrm{cc}$. 6II InOH, 1 cc. acet10 aold (1-2), heat on a seam bath for 20 mimutes, and dinte to a volume of $10 \mathrm{cc}$. and catrifuge. The precipitate oontains the 1ron and the supernatent 11quid the aluminum. Transfer $5 \mathrm{cc}$. of the 11quid to a $50 \mathrm{cc}$. volumetrio flesk. Add $15 \mathrm{co}$. weter and the

allute HCl wet11 11 tmas paper on the plask just turns red, and make up to rolume.

Dotermine the aluminum in the following manner. Transfer an allquot of 5 to $20 \mathrm{cc}$ (which should be only slightfy acld) to a $50 \mathrm{cc}$. volwnetric flack, add water to make rolome of $20 \mathrm{cc}$. Add 5 oc. of 5 I anonium acetate solution, 5 oc. of 1.5 I HCl and 2 cc. of a 0.1 per cont solution of aluminon. Allow to stand 20 minutes for the color to avelop, add 5 co. of 5I ammonium ohloride solution, then add suffi- 
- lent 3.2I ammonium carbonate solution to make the pH 7.0 to 7.1 . Make up to rolume and allow to stand for one-half hour. Then compare in a Alorimeter with a water solution containing a known quantity of aluminum which has had the color developed in the same manner.

Blanks should be run on all reagents used and the quantlty of aluminum found, if any, deducted from the amount found in the unimown.

\section{So118 \\ Description of So11s}

The solls seleoted for this work were taken from varlous plats on the Phode Island experimontel field, their prevlous fert1lizer treatment being a matter of record. The solls selected were chosen for the following reasons:

1. They had recelved different fertilizer treatment. 2. They were of varlous pH values, from strongly acid to marked ly alkaline.

3. By using these so1ls it wes thought possible to compare two or more factors. Solls from plats 25 and 29 had recelved Iime in the form of carbonate but had recelved nitrogen from different sources; 801125 from ammonlum alphate and soll 29 from nitrate of soda. So11s $55 \mathrm{~N}$ and $56 \mathrm{~N}$ had been treated alike excopt for the emounts of 11me applied. The same is true of 80118 from plats $65 \mathrm{~N}$ and $66 \mathrm{~N}$ but these had recelved three times the qrantities of phosphorlo acld that had been applied to the former so1ls. Fith these two solls the effects of alfferent quantities of 11 me and phosphoric acld as well as the effect of the two fertilizer elements in the presence of each other could bo compared.

So118 745 and $82 \pi$ should show the effects of fertillzer with and without 11me. So1ls from the market garden area Show the effects of manure and peat. 
4. Another important reason for selecting these particu-

lar 80118 was that crops of spinach la crop very sensitive to

toxtc aluminum) had shown marked differences in jields on these different solls.

The soils used, firtiliz $\mathrm{r}$ teatments, pH values, lime requirement, and yelds of ulnach in bushels per acre are shown in table 1.

\section{Ac1d Extraction of Sollo}

Extractions of the chosen so1ls were made w1th $0.5 \mathrm{I}, 0.1 \mathrm{I}$ and $0.02 \mathrm{I}$ sotic acid. The extractions with $0.5 \mathrm{~S}$ acid as used by Burgess (6) had not shown the amall differences in active aluminum which were reflected in yields of minach. Eepecielly was this tree with solls from the Whet-garden area where differences in "active" aluminum bad never been as great as in some other s0110,2lthough differences in yields of pinach had been noted. It was hoped that extraction w1th $0.02 \pi$ ac1d would show differenoes more closely correlated with $71 e 1 d s$. The quant1ties of "active" aluminum extracted from the solls by the various strengths of acid are shown in table 2.

\section{Disouesion of Results on Solls}

Roferring to the tables montloned above it appears that with 8011 . 25 and 29 extractions $\nabla 1$ th 0.21 ac1d show results for "activen aluminum arch as might be expected from the $\mathrm{pH}$ and $11 \mathrm{me}$ roquirement. The same rolation is noted when the ylelds of spinach and "aptiren aluminum are compared. "Active" aluminum content as shown by extractions with other ftrongths are exactly revorsed from what would be expected from pE value and Nields of eplnach.

Gomparing solls 55N and 56N, the results for "active" aluminum with all extractions are in accord with what might be expected from the pH and are In eccord with results seen for jlelds of spinach. With solls $65 \pi$ and $66 \mathrm{~N}$, only the results from extrection with $0.5 \mathrm{~N}$ acld are such as rould be expected from the pll value. The ylelds of epinech are in 
sooord with the aluminum results obtained with $0.5 \pi$ acid extraction.

$\Delta$ comparison of results on the above four s011s indicatebtho value of phosphoric acid in reducing the quantities of "aotive" aluminum and this fact is further shown by the spinach jields (table 1). The amounts of "aotiven eluminum obtalned by extraction with $0.02 \pi$ acld bear a closer relation to the Jields of splnach than do the others.

The beneficlal effects of Ilme when used with fertilizer are shown by the results on solis 745 and $82 \pi$. All results are in agreement with the jlelds for spinach, that orop being a failure on 8011 82N and not Frisedy different on 745 from the yleld on $801155 \mathrm{~K}$. Even though the alminum content does not agree especially well with the results on the above plats the egreement with the $0.02 \mathrm{f}$ acld extraotion 18 oloser botween $801155 \pi$ and 745 than with any of the othera.

Results from the market grarden area with all extractions are in accord with what would be expected from the pH values but are exactly opposite from what 18 indicated by the ylelds of eplnach on the two 0118. No alvmimum determinations made prerlonty have shown the alvininum content of the peat 8011 to exceed that in the manured 8011. This fact makes it evident that "active" aluminum is not responsible for the poorer growth of gplnach on the peat soll. It may be noted, however, that the active aluminum content of the solls and the ylelds of pinach are in accord: the amounts as extracted with $0.02 \mathrm{~N}$ acid howing the anallest differences and thus agreeing with the differences In the solls as indicated by the jlelds of spinach. The quantities of "active" aluminum extracted by $0.5 N$ acld are larger than the amounto found by Burgess and Pember (5). This might be explained by the fact that the solls used in these determinations had all pessed a $2 \mathrm{~mm}$. aleve, whlle those used by Burgess were not so flne and the acld extract: arminum from the fine material to a greater extent than from the coarse. 


\section{Crops}

Crops Grown in Solution Cultures

The orops selected were buckwheat, oats, and Jepenese millet. These were chosen for the reason that it has been shown by the work of Holean on solution cultures, analysis by the writer (table 3), that these plants when grown in weter oultures oontaining various amounts of aluminum vere able to make considerable growth, and also to extract from the colution appreolable amounts of aluminum.

\section{Glasshouse Culture}

The crops were grown in the greonhouse using Wagner pot 11110 d Wth the celeoted s0118. At the time the pots were fllled one gram Taro ${ }_{3}$ was thoroughly mixed with the soll in each pot and one-half gram more was added in solution to each pot on February $2,1929$. To correct for a lime laduced olhorosis, manganese eulphate at the rate of 25 pounds per acre was added on January 29, 1929, to pots 19 and 20 containing millet growing on $801155 \%$; to pots 29, 30, 154, and 156 containing oats growing on so11s 55I and 74S. Pote 35 and 36 oontalning the same crop growing on soll 65N recelved the same treatment on Jannary 30, 1929,

\section{Discussion of Results with Plents}

\section{Buckwheat}

This crop was hartested February 25, 1929, 91 daye after planting. The plants had practically completed vegetative growth and ripened a fer seeds. Many green seeds and a fev late blossoms were present. Tho plents were dried, ground, and the aluminum determined according to the wothod given above. The green- and dry-matter weights, the aluminum eontent of the plants, together with the quantities of aluminum remored per pot are shown in table 4 .

From this table it may be seen that there is, in most cases, a very Ol0se agreement in the ary-matter velghte from duplicate pots, the great- 
ost variation being 2.6 grams and the average 1.9 grams.

Considering yields, the largest was on 8011 from the marlset garden manure and treated with lime and

area pertilized with mangenese. This soll showed next to the smallest content of "active" aluminum when extracted with $0.5 \mathrm{I}$ and 0.021 ac1d. (3able 2).

The mallest yleld was from soll 56N. This soll showed the second largest content of "activen aluminum by all extractions. Those results are in accord with the pll velues and 11 gures for the lime requirement (table 1). Y1elds from soll $82 \pi$ which has the highest "activen aluminum content, is the exact average for the entire series thros showing that large amounts of "getive" aluminum in the soll do not serlously depress the growth of buckwheat plants.

Solls from Plat 90 of the market garden area had the lowest "active" alominum content, and this is reflectod in the quantity of aluminum in the erop, but for some reason the welght of crop was not as large as on sereral other so11s. Flelds of crops on this plat have been persistont:ly 10 .

Ho evidence is shown of material benefits from large applications of phosphoric acid or $11 \mathrm{me}$.

Regarding the quantities of aluminum removed per pot it is seen that thore is a close relation between amounts removed and the "activen alvinimm content of the 8011 in the following cases:

1. Extractionswith 0.5N acid, $8011829,55 \mathrm{~N}, 745,82 \mathrm{~N}$, 90 , and 118.

2. Fetrection s with $0.1 \pi$ acid, s0118, 25, 29, 65K, $745,82 \pi$, and 90.

3. Atractions with $0.02 \pi$ acld show fair agreement for $0011856 \mathrm{~N}, 65 \mathrm{~N}$, and $82 \mathrm{~N}$.

Considering the quantities of aluminum removed from $8011865 \mathrm{~N}$ and 66N there is some Indication that phosphorus inhibits the taking up of aluminum by the plant. There is no evidence of a similar effect in the 
.0260 of Iimo.

Fesults on buclewheat are in accord with those obtained by Molean (table 3 ) Who found that large quantities of aluminum ald not depress growth and that fasreased amounts of this element in the oulture solution were nected in the aluminum oontent of the plant.

Judging from the above results it would appear that the aluminum coatent of brokwheat is a good indloator of the amount of "ectiven almimum in the soll as shown by extraction with $0.1 \mathrm{~N}$ acid.

\section{M111et}

On March 18, 1929 when this crop wes hervested, 111 days after planting, it had made good growth. All plants had formed heads contelning more or $108 \mathrm{gra}$. The green and dry-metter velghts, the eluminum content of the plants, and the quentitles of aluninum removed per pot are ahom in table 5.

From the above table it $\mathbf{w 1} 11$ be seen that the agreement in weight Detween duglicate pots is not as close as with buckmeat.

M11et made its best growth on s0118 25, 29,90, and 118. The sirst two are solls from the lime experiment with pH values well up toward alkaline conditlons. The two latter solls have pH values within the alicaline rango. The yleld on soll 128 is the highest of the millet series.

Pamparing the flelde on the four so11s 55N, 56N, 65N, and $66 \mathrm{~N}$ we Ilnd those on the two letter solls materially iarger than on the former. This is marked Indication of the beneficiel effects of phosphorlo aold on millet.

Plants on 8011745 were 80 affected by chlorosis as to make $11 t t 10$ Growth and are not further considered.

On soll $82 N$ which 18 the most acld, the plants made slightly Wotter growth than on so11 66N. This result cannot be due elther to Ine of to inoreased anounts of phosphoric acld. with millet as with 
Wokmbeat on the market garden ares, the yield on soll 118 is superior to that on 801190 , agaln showing the charecterlstic depresalng effect of the peat soll.

Whe aluminum removal of the millet both in the content of the plant and the quantitieg removed from the soll per pot are very much smaller than was found with buckwheat. This again is in accord with the results obtained by McIean (table 3). The great difference in aluminum content between the two crops is especielly noticeable in the results on soll 62N. Millet grown on this soll contained the largest quantity of aluminum, but because of the dry welght of crop, it did not show as largo a Fenoval of aluminum from the so11 as did the plants grown on 8011118. Wretically no difference exists between the results obteined on solis $55 \mathrm{~N}$ and $56 \mathrm{~N}$ elther in the aluminum content of the plants or the quantity removed from the s011. With $011865 \mathrm{~N}$ and $66 \mathrm{~N}$ there 18 only a very amall difference in the aluminu content of the plants, but because of the difference in the dry matter there is much variation in the cuantity of aluminum removed from the soll. Comparisons of the four so1ls give but slight indications that larger applications of phosphoric acld decrease the aluminum content of the plent. As was the case with buckwheat, millet plants from $801182 \pi$ contained the lergest gavantity of aluminum.

Plants grown on so11 90 and 118 have an eluminum content which is about the average for the series. With this crop, In only a fer cases Is there shown any relative agreement between the "active" aluminum of the 8011 and the amount of that element in the plants. The amount rcmoved from soll 25 shows some agreement with the "ect1ve" aluminum as (otermined from extraction with 0.1 fi acld (table 2).

As was true with buckwheat the high "activen aluminum in $801182 \mathrm{~N}$ 1. reflected in the high aluminum content of the millet plants grown on this soll. 


\section{Q ats}

These were harrested April 5, 1929, 115 days after planting, The plants had made excellent frowth and some plants had started to hord. In a few cases smut was seen. The green-and iry-metter weights, the cluminum content of the plants, and the quantities of aluminum removed per pot are shown in table 6.

Considering this table it is seen that plants grown on solle 55N and 90 give very poor agreement in glelds from duplicate pots. Results Irom pot 29 are discarded as obviously defective. Also there 18, In case of 136 and 139,801129 , a wide variation in the aluninum content of the plants. The same 18 true for pots 41 and 42.

Oats made the best growth on so11s 25, 29, and 90 respectively. pomparing the flrst two s011s, there is a slightly larger yleld on s011 25. This so1l recelred 1ts nitrogen from sulphate of amonia.

Comparing the harvest whlghts from solls $55 \mathrm{~N}$ and $56 \mathrm{~N}$, It appears that the best growth was mede on 8011 whlch had recelved the lesser amounts of lime, and the same relation is true with s011s 65I and 66r. These results are not in reeping with those found with brackheat and millet. Contrasting the flelds on the above four s011s, the beneflolal offects of 1ncreased phosphorlo acld appear; this fact has been true With both the other crops grown.

Wolghts of the oat orop grown on 8011 745 were less then those produced on soll 82N. This hes also proved true with both buckwhert and allet. The need of so11 74S for more manganese may explein this fact. Yolds of oats from the market garden solls indicate the superiority of manure over peat.

Oonsidering the aluminum content of the plants, it is again shown that plants grown on the soll containing the largest quantity of "activen arrainum contain the most aluminum. Results from s011s 55N, 56I, 65N, and $66 \pi$ show that in the absence of 2 arge amounts of 11 me the aluminum 
content of the plent increeses: also that largo quantities of phosphorlc cold are correlated with better growth and $\mathbf{w}$ th increased aluminum in the plent.

As was found with the two other crops, plants from soll 821 contalned the most aluminum, wh1le the plants grown on soll 745 had a somewhat maller aluminum content. The beneflcial effects of lime and manure in moressing the welght of the crop are found to be the same in decreasing the aluminum content of the plents.

Although the quantitles of aluminum removed by duplloate pots do not agree in several cases, yet the relation between the average removal from the two pote 18, with one erception, the same as was found for the other crops. The except10n was on 8011890 and 118 where there was the same removel from each 8011.

\section{GENERAL DISCUSSION}

It may be possible to obtein goneral comparisons of value if an elwainum sensitive orop is nsed as an inder. Reference is therefore made honceforwerd to jlelds of splnach as shown in table 1.

The beneficial effects of lime upon ylelds of spinach are very motlceable between s0118 55N and 56N. The same holds true for buckWheat and millet but is not true for oats. With so118 $65 \mathrm{~N}$ and $66 \mathrm{~N}$ the dvantageous effects of 1 ime when used with larger applicatlons of phosphoric acld are very marked. This relation is not found with any of the three crops grown.

Pouparing ylelds of epinach from 8011 . $56 \mathrm{~N}$ and $65 \mathrm{~N}$, the desirable results Irom Increased amounts of phosphorlc ac1d are very noticeable. The same effect is seen with buckwheat, milet, and oats being more prominant with milet than with the other two crops.

The great differenoes observed with splnach on 80118745 and 821 are in no wey reflected in the Felds of the three orops grown, which are in no measure as sensitive to aluminum as is spinach. Solls from 
the market garden area, 90 and 118, give varietions in the yield of pirach which are conoordant with those noted with buolowhert, millet, and oats, the differences with these belng greater than with eginach. The value of Iime as a corrector of the injuriou effects of alumimm is shown much better with a sensitive crop like splasch than with the particular orops need in this work.

In view of the sensitivity of apinach to alminum, it would be expocted that the "active" aluminum in 801129 would be 1088 than that In 501125 . This proved to be true with the quantities obtained with $0.1 \mathrm{~N}$ sold extraction (teble 2) although the differences shown with 0.021 acld entraction are rery mall.

So11 56N 18 mach more sold than 55N and would be expected to contaln more "eotive" suminum. This was found to be true with all strangthe of sold used for extraction and the difference is reilected in the yleld: of upineoh.

Y1elds of minach and pH ralues would indioate that soll 66 N oontaine more "actiro" alvilinum than 6ar. This is found to be true with 0.5 acld extraction. The fallure of this relation to appear by extrections with other strengths of acid might be explained by the fact that Wh the amounts of phosphorlo ac1d used the alumimum was precipitated and not taken out by the more dilute concentration of the acids.

8011 82N, the most acld of the group, falled to produce a crop of pinach. From this we should expect this soll to have a high "actiren Mnminum content and this proved true with all strengthe of acid. This 0011 contained the largest quantity of "active" aluminum of the serios. The good yield of opinach on soll 74S, which may be due to the application of manganese, was but 11ttle maller than that on so11 55N. This would Indicate a slightly higher oontent of "actiren aluminum in this so11. This proved true only with extrections $\nabla 1$ th $0.1 \mathrm{I}$ ac1d. To Judge erom the pH of the two solls we would expect $801155 \mathrm{~N}$ to have the 
puter "active" aluminum oontent. This wes true with the extractions with $0.5 \mathrm{E}$ and $0.02 \mathrm{2}$ actd.

Ueing ylelds of aplnaoh 28 an Indicator we would expect soll $55 \mathrm{~T}$ to contain 1088 "active" aluminum than elther $56 \mathrm{~N}$ or $66 \mathrm{~N}$ and more than 65N. Thls proved to be true with the extraction with $0.5 \mathrm{I}$ ac1d. The pH ralues of the four solls would indicate that $801156 \pi$ should contaln the most "act1ve" aluminum. Th1 was found to occur w1th all strengths of acid used.

Sonsidering the spinaoh crop on the two solls one would expect only mall differences in "active" aluminum in the two solls from the mriet garden area. Butraotion with 0.02 acld agree with the above diffarence. 1180 we Bhould expect 801190 to have the larger "ective" alvminum content. This was not found to occur. On the contrary the seaults Ior this element were what might be expeoted from pll values, thus the howing that "ective" aluminum may not be ${ }_{\wedge}$ cause of the effects noted rpon splnach grom on this soll.

The relations between the "activen eluminum content of the solis and the gruantities of this element found in the plants is show in Figure 1. In this the largest quantity of aluminum has the value of 100. From this figure it is seen that in only one case (s011 82I) is the relation between the aluminum content of the plant and the quantitles of aluminum found in the 8011 by all extreotions the seme. With Artrections with $0.5 \mathrm{~N}$ acid we find agreanonts in the sluminum content of plant and 0011 as follows:

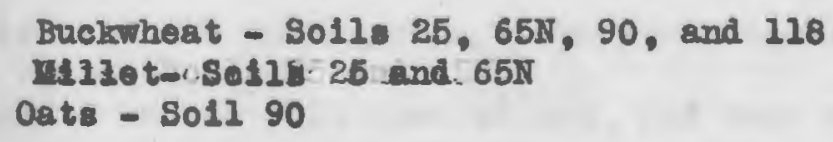

With $0.1 \mathrm{~N}$ acid agreement occur as follows:

Buclewheat - So11 $66 \mathbb{N}$ and 90

Iillet - So11s $56 \mathrm{II}$ and $65 \mathrm{I}$

Cats - So11. $66 \mathrm{~N}$ and 90

Ixtractions with $0.02 \pi$ acid show the following cases of agreement, 
Brokwheat - S0118 29 and 118

11110t - S0118 29 and $66 \mathrm{H}$

Oats - Sol18 25, 65N, and 118

The above tabulation indicates that extractions with $0.02 \pi$ acid Gres the best agreenent between the aluminum content of the plant and the "ective" alumirum in the soll.

Ilme with smiler quantitios of phosphorio acid as compared with Fophoric acid alone apparently lowers the quant1ty of aluminam in the plant. Iarger quantities of phosphoric acid lower the aluminum content of the plent in the case of millet and oats. In this connection it would be interesting if the quantities of aluminum in the aplaach plants could be known to see if the above facts were true with a sensitive crop.

It was found by Mchean (teble 3) that in solution cultures the largest jleld was with oats. Buckwhest and millet ranked socond and third. It was also found by the same worker that crope grown in the colution conteining the most aluminum shored the greatest aluminnm content per plant. This last is wholly in accord with the eindinge in this work.

The quantity of aluminum removed from the 8011 per pot is dependent both upon. the growth and the aluminum content of the plant. Brackineat. alfhough 1tdid not have as large a growth 8 millet or oats because of the high aluminum content of the plant, removed materially more than the other orops. M1llet, because of the amaller quantity of eluminum in the plents, renoved mach less aluminum from the s011. Oats with the largest Mrvest welght of the three crops grown removed but comparatively 11 ttle nore aluminum from the soll than millet, and rery moh less then buokmoat.

Breseale (4) has advanced the theory that the tolerance of plants to allali is the result of enviroment and adaptation to this substance through many generations. Poseibly the same reasoning might explain 
the large aluninum content of buckwheat with no depressian in growth. What 18 a member of the family Polygonaceae, which famlly 1 able to wake cutisfactory growth in poor and ac1d soll. and it may be trat through maturles of existence under such conditions this plant has aoquired the ablilty to atore up largo quantitles of alminim wi thout serlous growth pression. Buokwheat would, without question, be considered in that group of plants which Krat aman (16) has callod "aluminum storing plants."

\section{SUMMARY}

In the preceding pages are stated certaln observations made daring the course of the work on methode for the determination of almuinm; the malysis of solls for this element; growth, and analysis for almminum of the crops used. These observations may be summarized as follows.

The 11terature relating to aluminum in so11, plants, and animal subctance: and to the toxicity of this element and Its asits to plant growth 1. reviewed. Various mothods for the deterwination of aluminum in soll and plant meterials are discussed. A oolorimotrio mothod for the determination of small amounts of aluminum in 8011 and plant materiel is deser1bed.

The past fert111zer treatment of the ten solls from the Khode Island Aplcultural Frgeriment station plats, pH values of these solls and their content of "activen aluminum as shown by extraction with $0.5 \mathrm{I}, 0.1 \mathrm{I}$ and 0.02 II acetic ac1d are shown.

The jields in bushels per acre of spinach grown on these solls are Aron.

The relation between soll acldity and ylelds of spinach are discussed.

The reasons for oboosing certain solls and crops for this work are stated.

The ylelds per pot of the chosen orops on the designated solls are Siron.

The quantities of aluminum in the plents grown on the various soll, 
also the relation between nectiven aluminum in the so1le and the quantity of that element in the plant is shown graphically.

The effect of 1 ime and phosphoric acld on the "activen aluminum of the so11, slso the effect of these two substances on the aluminum content of the plant 18 discussed.

\section{CONCLUSIONS}

As a result of this work the follewing conclusions appear justified.

The described colorimetric method for the determination of small morints of aluminum 18 superior to 811 prevlous ones beceuse of the fact thet amsll quantitles of phosphorus as found 2080118 and plant material are not troublesome, and that iron is no longer a source of error.

With no one. of the crops used is there complete agreement between the aluminum in the plant and the "active" aluminum of the 0011 as shown by extraction with the three strengthe of acid ueed.

Differences in "active" aluminum in the 8011 as indicated by yields of spinach are in falr agreement with the amounts of "activen alumiunum axtracted by $0.02 \pi$ acetic acid.

The quantities of "eotiven aluminum extracted by 0.5 II acid and the aluminum content of buckwheat are 80 largo as to be useless in indicatIng anall differences of "active" aluminum in the so11. For a crop consitive to aluminum toxicity the quantities of "active" alumimum as shown by extractions with $0.02 \pi$ acetic acid are of value.

Large quentities of "aotiven alumimum in the soll are corvelated Wth large aluminum content of the plant. This fact, together with the different quentities taken up by buckwheat, millet, and oats are In agreement with results obtalned in culture solutions.

Results on a soll supplied with peat and limed to neutrality ind1cate that "activen aluminum is not responsible for the effects noted in the growth of orops on this roll. This is in agreement with rosults which have been obtained several times previously. 
The boneficial effects of 1 ime and phosphoric acid on plants in the presence of considerable quant1ties of aluminum are in agreement with reoults noted by several previous workers.

Cusidering the results obtained vith buckwheat, willet, and oats there are no Indications that the use of these plants as indicators for the nactiven aluminum content of the soll is apperior to extractions with $0.1 \mathrm{I}$ or $0.02 \pi$ acetic acid, especially when the length of time messary to complete the two determinations 18 considered.

The writer desires to express his thank to Dr. B..B. Gilbert and to H. J. B. Smlth for the1r lindy advice and constructivo oriticiom and also to ecknowledge the assistance of Mr. F. R. Pember under whose direction the erops used in this stady were grown. 
(1) Abbott, J. B., Connor, S. D., and Smalley, H. R. 1923 Soll acidity, nitrification and the toxic effects of soluble alts of aluminom. Ind. Agr. Ergt. Sta. Bul. 170.

(2) Atack, F. W. 1915 New Reagent for the deteotion and colorimetrio estimation of aluminum. Jour. Soo. Chom. Ind. 34: p. 936.

(3) Blum, W. 1916 The determination of aluninum as oxide. Jour. Amer. Chom. S00. 38: p. 1282 .

(4) Breageale, J.F. 1926 Alcall tolerance of plants considered as a phenomonon of adeptetion. Ariz. AgP. Bxpt. Sta. Tech. Bul. 11.

(5) Bargess, P. S., and Pember, I. R. 1923 "Lotiven aluminum es a factor detrimental to crop produotion in many acid so1ls. R. I. Agr. hrot. Sta. Bul. 194.

(6) Bargess, P. 8. 1925 A wethod for the determinetion of "ective" aluminum in acid s0118. So11 Se1. $15, \mathrm{p} .131$.

(7) Connor, S. D., and Sears, O. H. 1923 Aluminum salts and aclds of rarying hydrogen Ion concentrations in relation to plant growth in water cultures. Soll so1. 13 . p. 23.

(8) Corel, F. V. 1926 The effect of aluminum sulphete on rhododendrons and other acld soll plants. Smlthsonian Inst. Annual Report, p. 369.

(9) Donnison. I. 1. 1922 The neture of certain aluninum salts in the soll and their influence on nitriflcation and amoniflcationd So11 S01. 13: p. 81.

(10) G110, P. I. 1923 Methods of diagnosing toxio1ty. Jour. Amer. Soo. Agron. 15: p. 305 .

(11) Hardy, F. 1926 The role of alumimum in soll fertility and toxicity. Jour. Agr. So1. 168 p. 616.

(12) lartwel1, B. I., and Pember, F. R. 1918 Aluminum as a factor irencing the effect of acid solis on different crope. Jour. Amer. Soo. Agron. 10 \&. 45.

(23)

1918 The presence of alund num

as a resion for the difference in the effect of 80 called acid co11. on barley and ryo. So11 So1. 62 p. 259.

(14) Hoffer, G. I. 1923 socumalation of aluminum and Iron compounds in oorn plants and 1 ts probeble relation to root rot. Jour. Agr. S01. 232 p. 80 .

(15) Thlenberg, L, and Class, John C. 1929 Solenoe 69, no. 178.

(16) Kratzmen, I. 1913 The mioro-chemicel recognition and the distribrtion of eluminum in plants. S1trber. $\mathrm{K}$ Ared. W18s. [V1enna] Yath. Naturw. KI. 122 II, No. 2, p. 312. Abstract in Mrpt. Ste. Record $51:$ p. 129, seen.

(17) Ilne, J. 1926 Aluminum and ac1d so11s. Jour. Agr. So1. 16: p. 335. 
(18) Ilpman, C. B. 1929 The ohemioal composition of sea water. Carne810 Inst. of Washington Publications No. 391.

(19) Innde11, E. F., and Knowles, H. B. 1922 Determination of aluminum as phosphete. Jour. Ind. \& Fing. Chom. 148 p. 1136.

120 liaglsted, 0. C. 1925 The aluminum content of the soll solution and 1ts relation to soll reaction and plant growth. Soll 501. 20: p. 281.

(21) Yoce11m, I. V., Rust, O. S., and Becker, J. E. 1928 A trady of the poselble role of aluminum in plant and animal $11 f 0$. Jour. B101. Chom. 77: p. 753.

(22) IoIean, Forman T., and G11bert, Bas11 B. 1928 Aluminum toxic1ty. Plant Phye101. 3: p. 293.

(23) 1927 The relative alunimum toleranoe of erop plants. Soll Sc1. 24: p. 163.

(24) Mirasol, J.J. 1920 Aluminum as a factor in 8011 ac1a1ty. So11 So1. 108 p. 153.

(25) Miyaice, K. 1926 The toxic effect of solable aluminum salts upon the growth of rlce reedlinge. Jour. B101. Chan. 25: p. 23.

(26) Patten, 4. J. 1922 Report on the determination of 1 ron and aluminum, caloivm, and magnesium in the ash of seeds. Jour. Assoc. Off. Agr. Chom. 6: IO. 4 .

(27) Buprecht. Q. W. 1915 Toxis effects of Iron and aluninum on clorer seedlings. Mass. Agr. Ext. Sta. Bul. 161.

(28) Scott. W. T. 1917 Standerd Methods of Ohomical Analye18. D. Van Hostrand Co., Hew York.

(29) Souner, A. L. 1926 studles oonoerning the essentlal nature of aluminum and silicon for plant growth. Jour. AGr. Sol. 58 p. 57.

(30) Stolclasa, J. 1925 Aluminum in organic 11fe. International Inst. Agx. 3: p. 3 .

(31) Yoe, John H., and H111. W1111am I, 1927 An Invest1gation of the reaction of aluninum with the ammonium selt of arartn tricarboxyl1c ac1d under different experimental conditions and Its applioation to the oolorimetrio determination of aluminum in water. Jour. Amer. Chom. Soo. 498 p.2395. 


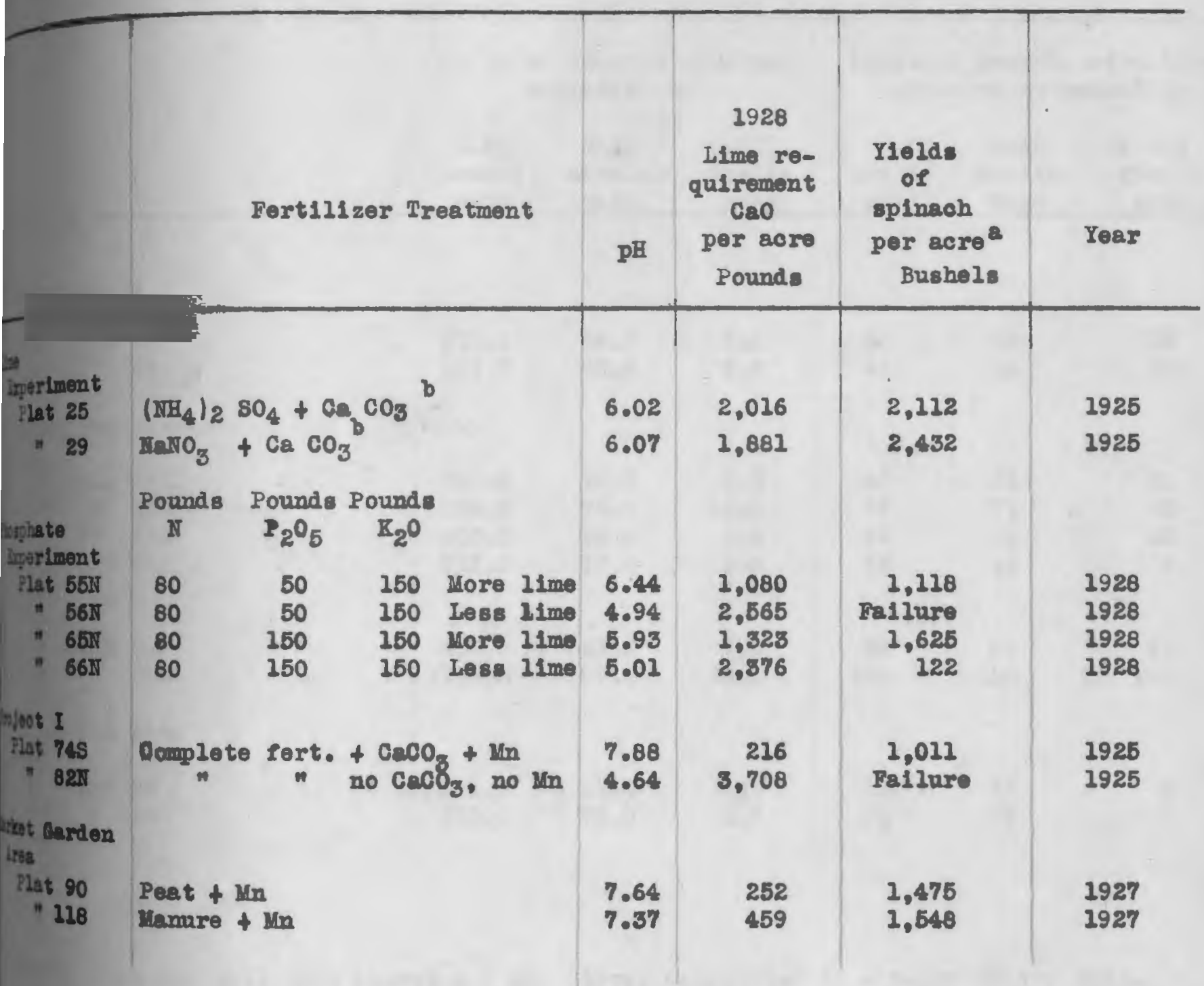

Ileat of buchal $=12$ pounds.

to clequate $\mathrm{P}_{2} \mathrm{O}_{5}$ and $\mathrm{K}_{2} \mathrm{O}$. 
Bxpe frown in solution oultures by lolean with anelyeis by Adems

$\begin{array}{llll}\text { Aluminum } & \text { Dry matter } & { }_{2} \mathrm{O}_{\mathrm{g}} \text { In } & \text { Mg. of } \mathrm{M}_{2} \mathrm{~g} \\ \text { welght of } & \text { crop } & \text { Recovered }\end{array}$
added. orop

in. 2.0 Grems

(Dry matter basis) (Dry matter basis)

1.80

7.20

4.97 Per oent

14.40

4.18

0.0252

125

0.0508

212

0.0398

125

7.20

9.35

0.0641

599

14.40

4.68

0.1090

520

28.80

4.00

0.1590

637

1.80

7.70

0.0375

288

14.40

7.47

0.0040

30

1.80

9.78

0.0299

292

3.60

12.37

0.0241

298

7.20

11.41

0.0353

402

14.40

12.65

0.0365

457

1.80

2.99

0.0225

68

3.60

3.99

0.5640

249

7.20

4.58

0.0857

413

14.40

4.12

0.2530

1045

1.80

1.62

0.0129

21

3.60

2.28

0.0329

75

3.22

34.40

4.04

0.0040

13

0.1430

577

1.80

9.74

0.1375

14.40

17.90

0.0811

1248

567

1.80

7.48

0.0965

732

3.60

5.71

0.0569

335

6.72

0.1080

616

28.80

2.01

0.0249

50

3.35

0.0975

326

1.60

2.08

0.0301

$-63$

3.60

0.87 .

0.4520

614

7.20

1.84

0.0522

96

24.40

0.44

0.0192

35

1.80

7.57

0.0194

147

3.60

7.20

9.03

8.22

0.0864

751

0.0672

652

1.80

0.67

0.2380

159

3.60

9.50

0.0413

392

.7 .20

0.78

0.1720

134 
TABLE 4

tholowhoat, aluminum content, and millierems cluminum removed by orop

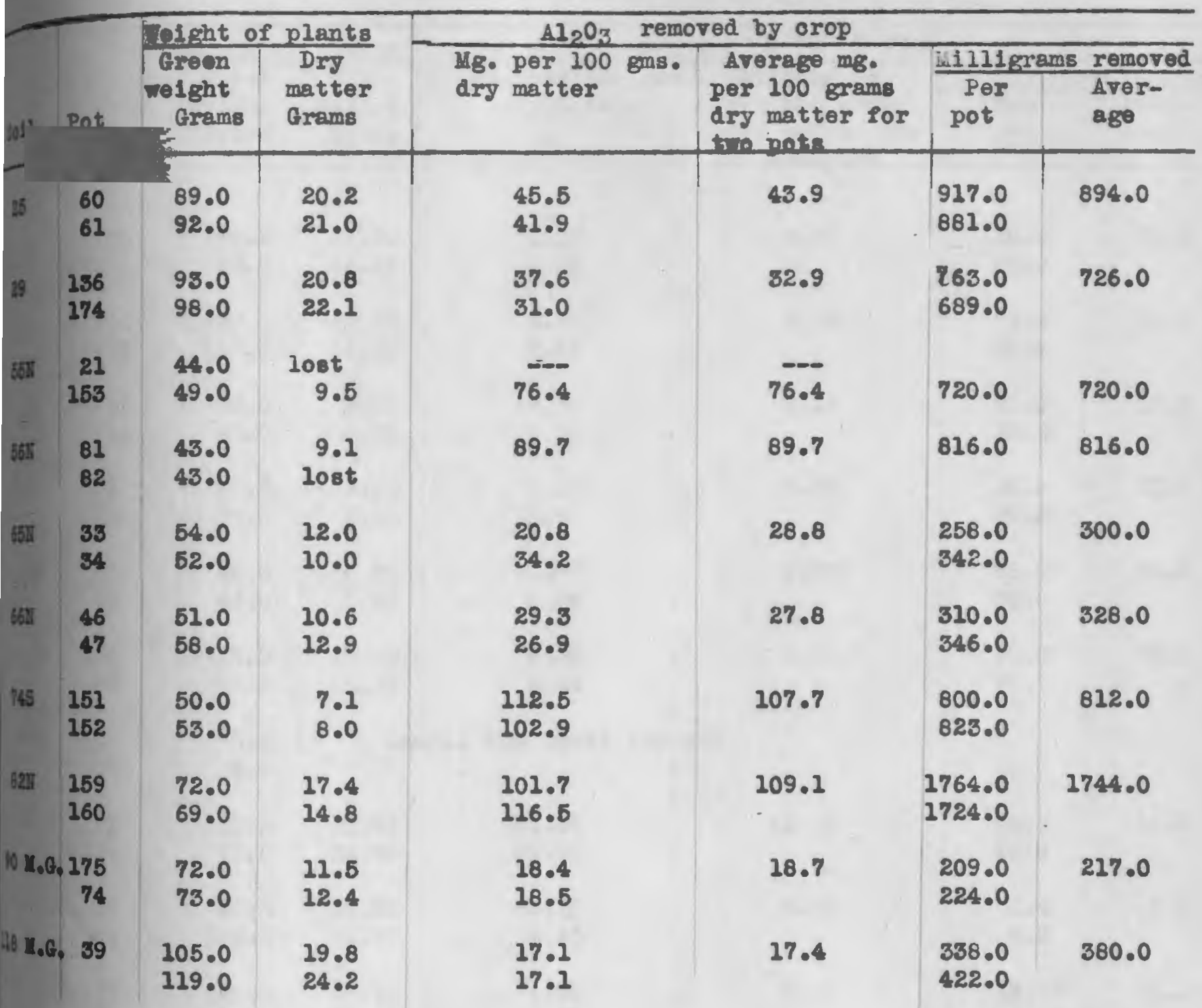




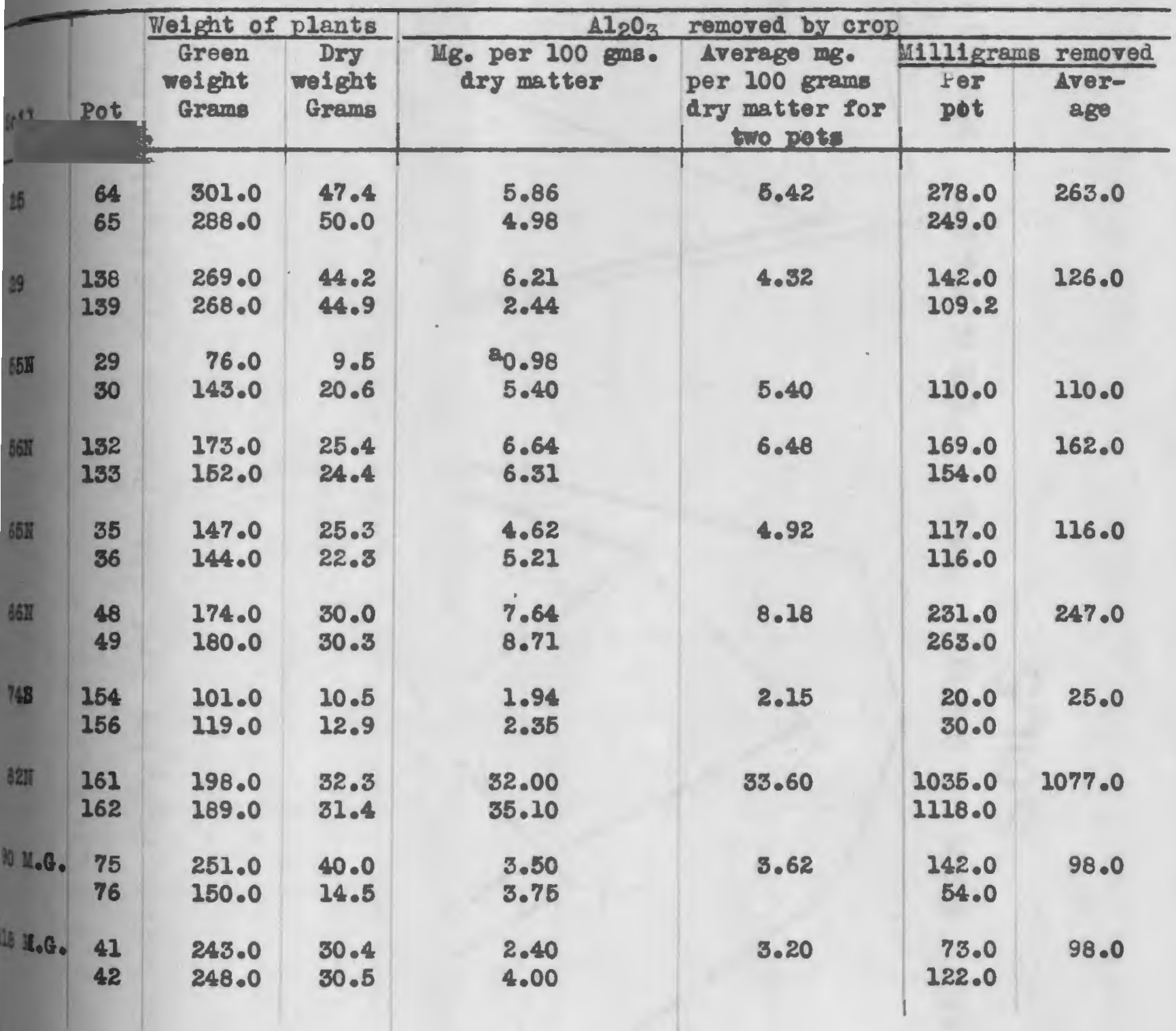

foults on this pot discarded. 


\section{FIGURE-I}

LATIONS BETWEEN AIO, IN THE SOIL AND IN THE PLANT PLOT 82=100

ENT OF PLANTS
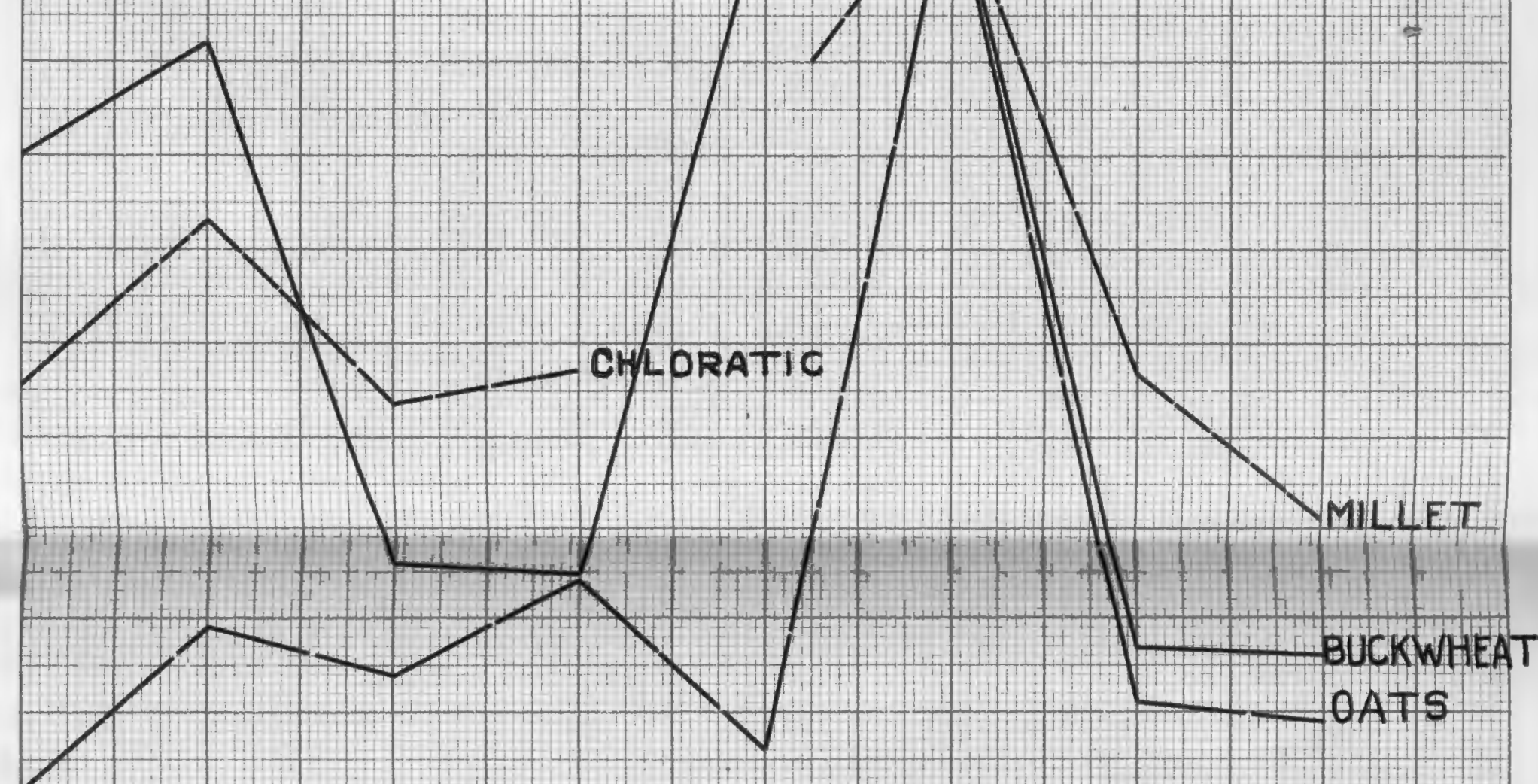

ENT OF SOILS AS DETERMINED BY

NWITH 3 STRENGTHS OF ACIDS

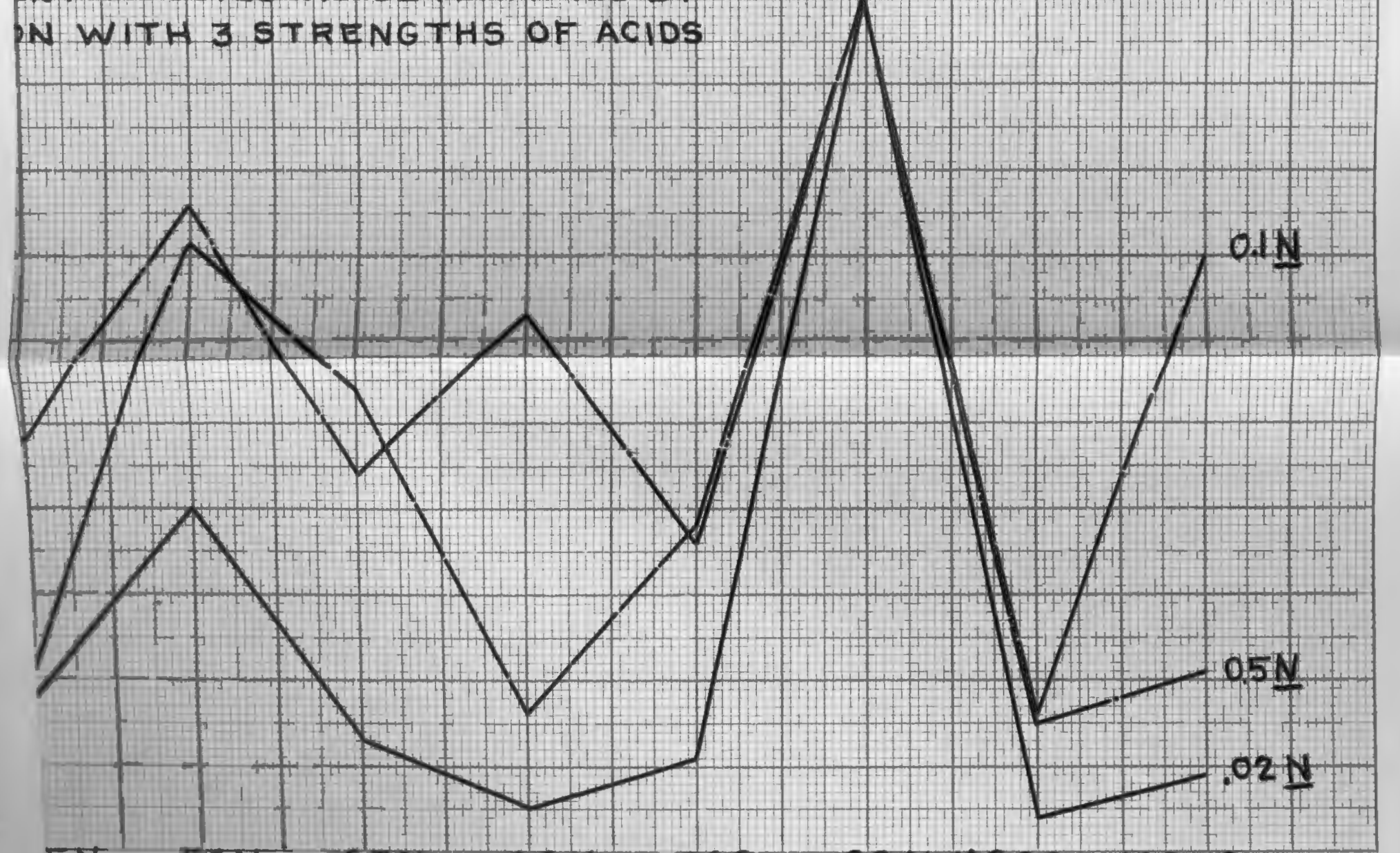

